\title{
Spatiotemporal trends for exotic species in French freshwater ecosystems: where are we now?
}

\author{
Beisel Jean-Nicolas • Peltre Marie-Christine • \\ Kaldonski Nicolas · Hermann Agnès • \\ Muller Serge
}

\begin{abstract}
We compiled a list of 148 exotic species in French inland freshwaters, comprising 36 plant species and 112 animals, including 50 invertebrates, 7 amphibians, 1 reptile, 25 fish, 22 birds and 7 mammals. Spatial distribution maps and cumulative analyses for most species indicate that exotic plants are distributed more along the west coast of France and, to a lesser extent, the Rhone basin, whereas exotic animals are clearly clumped in the north-east (Rhine Basin). The rate of introductions has increased exponentially over time. The
\end{abstract}

B. Jean-Nicolas $(\bowtie) \cdot H$. Agnès

Ecole Nationale du Génie de l'Eau et de l'Environnement de Strasbourg (ENGEES), 1 Quai Koch, BP 61039,

67070 Strasbourg, France

e-mail: jn.beisel@engees.unistra.fr

B. Jean-Nicolas

Laboratoire Image, Ville, Environnement (LIVE), CNRS

UMR 7362, Université de Strasbourg - 3, rue de

l'Argonne, 67083 Strasbourg, France

P. Marie-Christine

Université de Lorraine, Laboratoire Interdisciplinaire des Environnements Continentaux (LIEC), CNRS UMR 7360, Campus Bridoux, Rue du Général Delestraint,

57070 Metz, France most recent introductions (since 1992) have occurred in the Rhine Basin, from where they have then spread. Twenty-five species on our list are among the " 100 worst invasive species of Europe' (DAISIE) and 11 among the worst in the world (IUCN), with six species included on both lists. The potential cumulative impact of exotic species tends to be heterogeneous across France, though the north-east appears to be more disturbed, especially by animal species. Additional research is needed on criteria for prioritising intervention measures that will help stakeholders make objective choices in the management of exotic species in aquatic ecosystems.

Keywords Exotic species - Invasive species · Inland waters $\cdot$ Pathway $\cdot$ Xenodiversity $\cdot$ Rhine Basin .

France

K. Nicolas

Aix Marseille University, University of Avignon, CNRS,

IRD, IMBE, Marseille, France

M. Serge

Museum National d'Histoires Naturelles - ISYEB - UMR

7205 CNRS MNHN UPMC EPHE, Paris, France 


\section{Introduction}

On 1 January 2015, a new European Union regulation addressing the problem of invasive alien species (EU Regulation No. 1143/2014, 22 October 2014) entered into effect. The regulation identifies three types of intervention (prevention, early warning and rapid response) and suggests management measures to protect native biodiversity and ecosystems, and to minimise and mitigate the human health and economic impacts that invasive alien species can cause.

Today, almost all exotic species introductions in inland European freshwaters are unintentional, though usually human-aided (Gherardi, 2007; Gherardi et al., 2009; Havel et al., 2015). Human activities allow species to break out of their natural range and can lead to patterns of introduction that are difficult, or even impossible, to predict. Following introduction, exotic species may become 'invasive', i.e. they become numerically and ecologically dominant and spread rapidly from their point of introduction. The DAISIE project (Delivering Alien Invasive Species Inventories for Europe; www.europe-aliens.org), begun in 2005, has created an inventory of alien species that threaten European terrestrial, freshwater and marine environments (Hulme et al., 2009) and aims to gather one of the largest and most comprehensive databases on introduced species in the world. The DAISIE database presently holds 12,122 species in Europe, of which around 10 to $15 \%$ are invasive (EEA, 2012; Caffrey et al., 2014), and approximately 500 are inland water species (Data valid for 30 October 2015). Nevertheless, the database is relatively incomplete as regards spatial distribution, with only 18 species registered for France.

Despite growing interest in the field of biological invasions (Richardson \& Ricciardi, 2013), there is still a need to improve our understanding of species introduction dynamics, with the aim of managing the spread of exotic species and reducing their impact (Havel et al., 2015; Nunes et al., 2015). A first step in that process is the identification of all exotic species occurring in a chosen territory, followed by analysis of distribution and potential impact. Analysis of the mechanisms underlying previous invasions will also contribute to protecting aquatic ecosystems against the impacts of future invaders (Nunes et al., 2015). In the Laurentian Great Lakes basin for example, valuable predictive information was obtained from an analysis of invasion history and vector activity (Pagnucco et al., 2015).

In this paper, we describe the spatiotemporal evolution of exotic species introductions in France and their recent distribution. France is divided into six large river basins (Meuse, Rhine, Rhone, Garonne, Loire, Seine), with numerous smaller watersheds and many coastal rivers. This study is limited to aquatic species living in inland freshwaters, including connected waterbodies and their floodplains. The first symposium devoted to biological invasions in French freshwater ecosystems was held in 1996, with most of the talks being published in the 'Bulletin Français de la Pêche et de la Pisciculture' (now renamed Knowledge and Management of Aquatic Ecosystems) in 1997 (BFPP, 1997). Since then, several lists of exotic species have been produced in the 'grey' literature under the auspices of CEMAGREF (now IRSTEA [Institut national de recherche en sciences et technologies pour l'environnement et l'agriculture]; Dutartre et al., 2012), though with no spatial analyses. Here, we analyse temporal trends in rate of introduction, the relative proportion of each taxonomic group (aquatic plants, invertebrates, fish, birds, mammals) and the most impacted spatial basins. The potential risk of each species poses to the ecosystem was assessed on a three-level scale (low, moderate, high) for each of the 96 administrative counties in France (Corsica excluded), and the sum of potential risks for all exotic species recorded, allowing an estimate of cumulative potential threat per area. We explore these data to extract information that could a) help manage exotic freshwater species in the environment, and b) improve our understanding of the range of actions that may have to be implemented in areas affected by different species groups.

\section{Materials and methods}

Who is exotic and who is not?

The main aim of this study was to provide an up-todate registry of exotic species with self-sustaining populations in French freshwater ecosystems. Exotic species are defined here as those that have been introduced into France through human interference, either directly or indirectly, from a natural range outside France's borders. They reproduce consistently 
and sustain populations over many life cycles without direct intervention by humans (Richardson et al., 2000). The list was primarily compiled by gathering all available information from the grey and scientific literatures (Electronic Supplementary Material 1ESM_1). Cases of natural dispersal (e.g. Odonata sp.) or of translocation within or between French river basins were not included. Naturalised species (i.e. species where reproduction allows self-perpetuation of at least one population in the wild) were considered as 'exotic' if their introduction could be traced to within a 2,000-year cut-off limit. The register was strictly limited to hydrophilic and aquatic vascular plants, invertebrates (free-living species with $>3 \mathrm{~mm}$ adult size), amphibians, reptiles and fish, along with those birds and mammals that require freshwater to complete their life cycle. Due to the obvious gap in present knowledge of invertebrate taxa and the lack of any data on introduced parasitic species, the total number of exotic species recorded in the list almost certainly represents an under-estimate of French inland-water xenodiversity.

We did not include the beaver Castor canadensis (Kuhl) in the list as, while it was introduced into France in the 1970s, it has since been fully eradicated (Moutou, 1997). More recently, the ranges of beaver populations in nearby countries have expanded close to the French border; however, as yet there is no evidence that individuals have again established themselves in France (Dewas et al., 2012). Several exotic plant species (i.e. Ambrosia artemisiifolia (L.), Cortaderia selloana ((Schult. \& Schult.f.) Asch. \& Graebn.), Miscanthus sp. (Andersson), Senecio inaequidens (DC.) and Solidago canadensis (L.)) are occasionally observed in wetlands and along riverbanks; however, these have a low affinity for water and, therefore, are not included in the analysis. We also delisted Stratiotes aloides (L.) as it is not yet confirmed whether the lineage presently proliferating at several sites is different from that naturally occurring in France (through spontaneous colonisation). Furthermore, its cultivation origin has yet to be proven.

Information on exotic species

For each taxon, we recorded date of (first) observation as a naturalised species (Electronic Supplementary Material 2-ESM_2), potential impact, and the species' current distribution in France (before the end of 2013). Date of first introduction refers either to the exact date or the approximate year it was first reported in the scientific or grey literature as naturalised. To reduce any bias due to such approximations and the obvious delay between species introduction and data gathering, the data were separated into 20 -year intervals. Spatial distribution was analysed based on the present system of French administrative counties (Fig. 1). While the geographical boundaries of most counties are not drawn up on ecological principles they do represent distinct administrative units for which information is available. Furthermore, as exotic species introductions/dispersals are usually facilitated by human actions, river basin limits tend not to represent barriers to such movements. Nevertheless, we decided to overlay the geographic limits of large river basins (Fig. 1a) with metropolitan county borders (Fig. 1b) in order to analyse the number of exotics per large river basin (Fig. 1).

The potential impacts and disturbances caused by each exotic species (Electronic Supplementary Material 2-ESM_2) was evaluated along a three-point scale as either low, medium or high, based on expertknowledge. The method used to assign level of potential impact is described in Electronic Supplementary Material 3-ESM_3. As well as the potential impact on ecosystems (Havel et al., 2015), we also took into account any impact on human activities (such as biofouling) or human and animal health (Mazza et al., 2014). As regards this latter criterion, we included the Asian tiger mosquito Aedes albopictus (Skuse), which is a well-known vector of at least 22 human viruses (Butler, 2012), and several American crayfish species transmit American crayfish plague to native species (Holdich et al., 2009). While certain types of disturbance may also cause economic impacts, economic implications alone were not used to classify species.

The list thus produced has a variety of potential uses, including the elaboration of a na-tional checklist of exotic species, analysis of spatiotemporal patterns of exotic species introductions and highlighting and prioritising modes of action necessary at the infranational geographic scale.

\section{Results}

Our data indicate an exponential rise in the cumulative number of exotic species in French inland-freshwater 


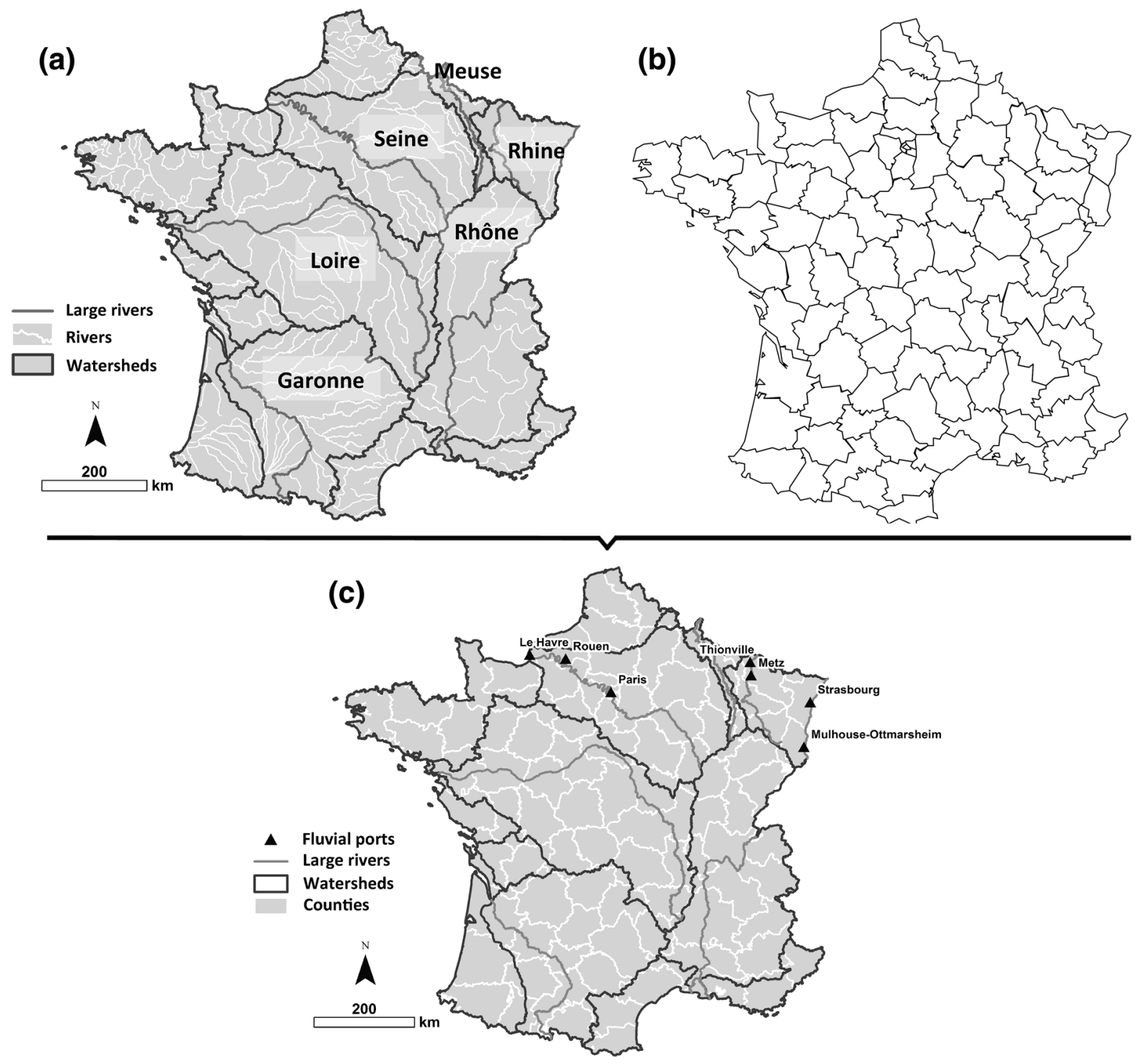

Fig. 1 a Map of the Meuse, Rhine, Rhône, Garonne, Loire and Seine hydrographic basins. Those not identified are smaller watersheds and/or coastal rivers; b administrative county borders; and $\mathbf{c}$ overlap of large hydrological basins and counties.

systems (Fig. 2). Thirty-five of the 136 exotic species with a known date of introduction were recorded before the twentieth century, 21 during the first half of the twentieth century and 56 during the latter half of the twentieth century. Since 2000, 24 new species have been recorded, representing an average of one new species each 6.5 months. None of these species (aside from the beaver) has subsequently been extirpated.
Note that the geographic limits rarely overlap. Triangles represent the seven most important river ports, based on annual volume of trade

Thirty-six of the 148 exotic species identified were plants (riparian and aquatic) and 112 animals, including 50 invertebrate species, 7 amphibians, 1 reptile, 25 fish, 22 birds and 7 mammals. For 136 species, we were able to analyse spatial distribution by county. Overall, the number of exotic species recorded ranged from 19 to 78 species per county, with counties along the northern border with Belgium, Luxembourg and Germany, or those situated in the alluvial zones of 


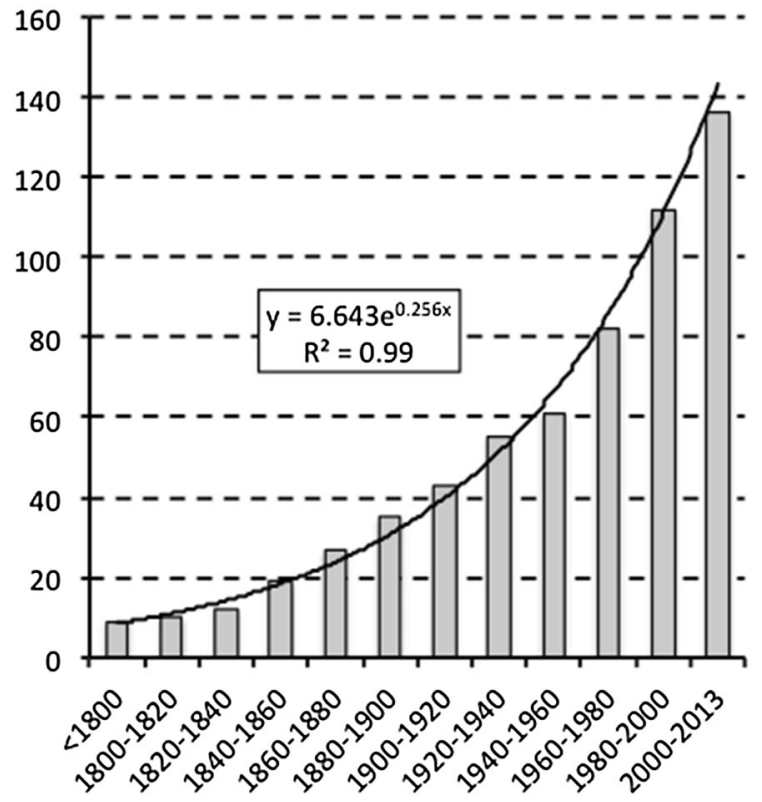

Fig. 2 Temporal trends for the cumulative number of exotic species observed in French freshwater ecosystems. We considered 136 species from the 148 identified, the first observation date for 12 of the species being too imprecise. The oldest introductions occurred centuries ago and have been summarised as before $(<)$ 1800. An exponential model was calculated using these data; however, the last period corresponded to just 13 years versus 20 years for the other periods (first period excepted)

large rivers, hosting more species. There was a clear dichotomy between plants (5-22 sp. per county) and animals (from 14 to 63 sp. per county), with northeastern counties distributed along the Rivers Rhine, Moselle, Meuse and Rhone having higher numbers of exotic animal species and counties along the west coast having higher numbers of exotic plants (Fig. 3).

Due to the high numbers identified (50 sp.; 0 to 28 sp. per county), the spatial distribution of invertebrates was very similar to that for animal species as a whole, with most species per county in the north-east (Fig. 3). Introduced mammal (1-6 sp. per county) and fish (5-17 sp.) species were also most numerous in the north-east (principally around the Rhine basin and adjacent navigation canals). Introduced bird species (1-16 sp. per county) were relatively heterogeneous, though fewer exotic species were recorded in the south. The low number of exotic amphibian and reptile species recorded was reflected in the low number of species per county (0-3). While such low number of exotic makes interpretation of distribution difficult, we can say that more exotic amphibians and reptiles tend to be found in the south (Fig. 3).

Although the date of first introduction for each species was used to calculate the cumulative number of exotic species per county, further analysis was based on the latest available distribution figures established in 2013 (Fig. 4). Based on these data, the recent (post 1990) spatial distribution of exotic species is clearly not homogeneous along the large river basins. More recently introduced exotic species are clumped along the Rhine basin (the River Rhine and its main tributary, the Moselle). High numbers of exotic species were also observed along the upper stretch of the Seine and along the navigable stretch of the Rhone. In contrast, the number of exotic species introduced per county prior to 1945, and between 1945 and 1990, tends to be spread relatively homogeneously over the country (Fig. 4).

Species with a low or moderate impact tended to be clumped in the north-east of France (Fig. 5), while counties with high numbers of high-impact species tended to lie along large rivers and canals, with the highest values recorded around the Seine estuary and along the Rhone near Lyon, the Escaut basin, the navigable stretch of the Moselle and along the upper Rhine.

\section{Discussion}

No sign of decrease in the rate of introductions

The number of exotic species being introduced into French freshwater ecosystems appears to be rising exponentially and shows no sign of decreasing. On a larger scale, Nunes et al. (2015), following Gherardi et al. (2009), found that introductions of alien freshwater species in Europe have been increasing continuously, and especially over the last 60 years. An average of three new exotic species has been recorded every 2 years in recent decades, most of them being animal species. While it is possible that this trend partially reflects the recent increase in monitoring effort directed at exotic species, many recent observations have been of relatively conspicuous species, such as the crustacean Orconectes immunis or the fish Neogobius melanostomus, which are unlikely to have been missed in the past. Despite a growing effort to detect exotic species, there is no doubt that some 

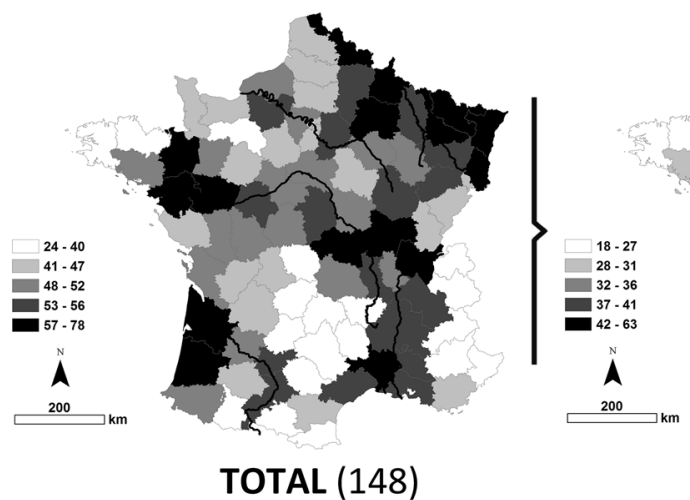

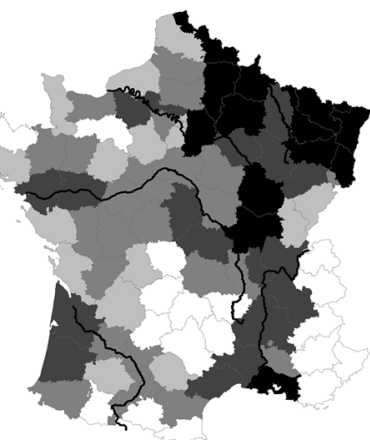

ANIMALS (112)

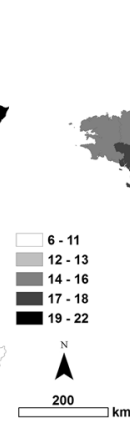

A

$\mathrm{km}$

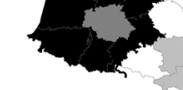

PLANTS (36)

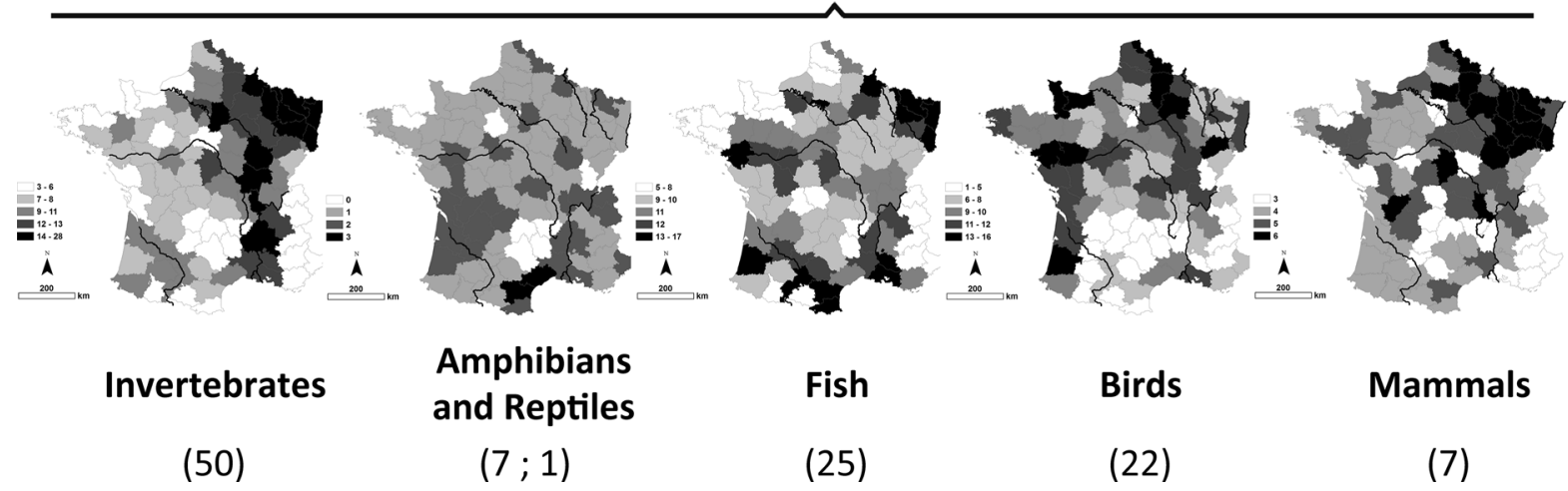

Fig. 3 Spatial distribution of the number of exotic species per county based on taxonomic affiliation (the number in brackets is the number of species in each taxonomic group)

introductions have gone unnoticed and there have been several cryptic species, particular invertebrates, which may have been introduced long ago. The amphipod crustacean Chelicorophium curvispinum (Sars), for example, was observed in France for the first time in the early 1990s, following its welldocumented spread along the Rhine and its main tributaries (Bachmann et al., 1997). At many locations along the Rhine, however, this species is now difficult to find as it has been replaced by its congener $C$. robustum (Sars), a species first observed 10 years after C. curvispinum but probably introduced several years before its first observation (Labat et al., 2011). Today, the morphological criteria for discriminating $C$. robustum are well known; however, they were not well known in the past and all Chelicorophium specimens were probably previously classified as $C$. curvispinum. While tools are now available to discriminate C. robustum and C. curvispinum (Piscart \& Bollache, 2012), a third species now thought to be present in France, C. sowinskyi (Martynov) (Forcellini, 2012), is easily confused with $C$. curvispinum and could already have discreetly spread along a number of large river basins.

A further source of underestimation may have been introduced by the bioassessment methods utilised by national administrative agencies in the past, which usually used a taxonomic resolution corresponding to the family or genus level. Such methods are unlikely to provide data capable of detecting exotic species in the early stages of introduction. While bioassessment methods by these agencies have, by necessity, tended to use a coarse level of identification not tailored to detect exotic species in the early stages of introduction, the fact that biologists are involved in the sampling of approx. 2000 river locations per year offers the possibility that they will recognise and report unusual species they collect.

The number of exotic species recorded in France (148) is very high and ranks alongside such xenodiversity hotspots as the Great Lakes of North America, where 180 exotic species have been reported (Bobeldyk et al., 2015). As no exotic species appear to have spontaneously collapsed to local extinction in 

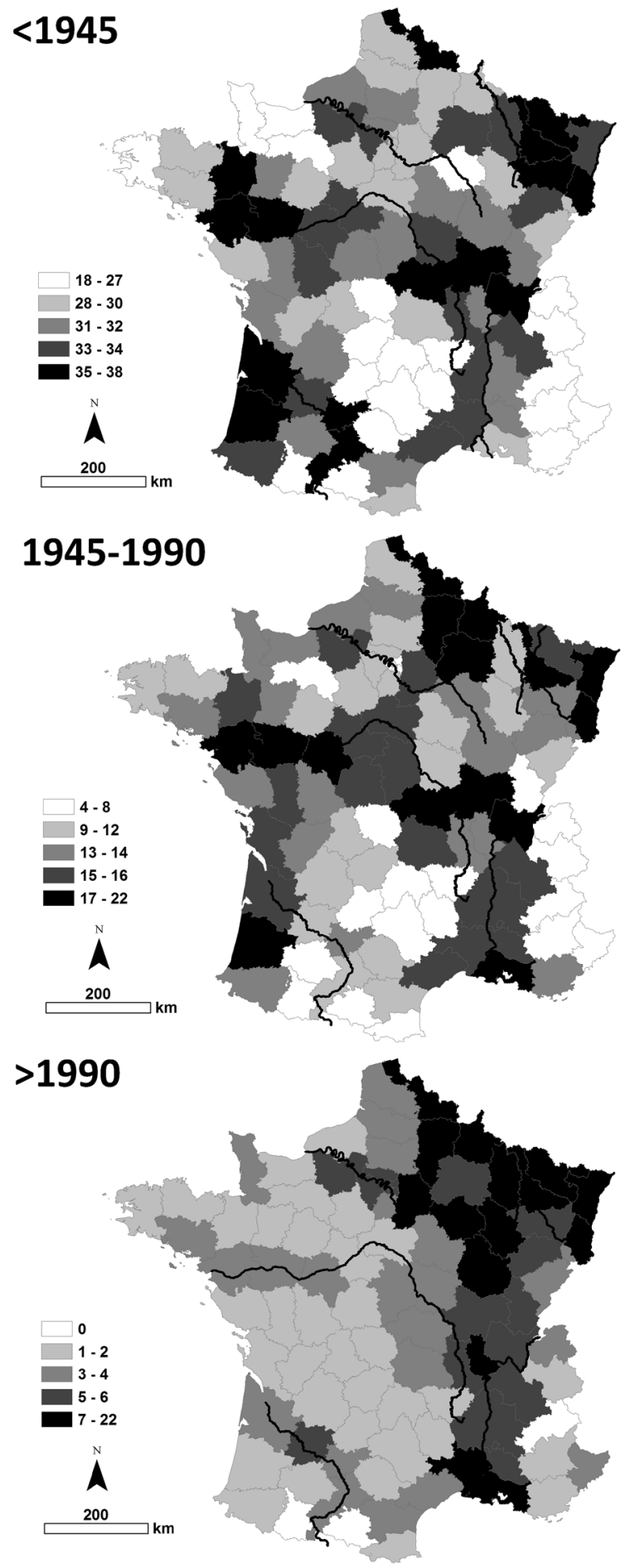

Fig. 4 Cumulative number of exotic species per county based on date of first introduction ( $n=136$ species). For each species, distribution is based on survey data from 2013
France, natural resource managers have no other choice than to deal with them now or in the near future.

Exotic plant distribution

Over the last 200 years, there has been a general shift away from intentional introductions for human use or wellbeing to unintentional introductions. Worldwide, the accidental (or intentional) release of ornamental and aquarium species has led to the establishment of over 150 species in the wild, including one third of all species registered on the IUCNs 'top 100 worst invasive species' list (Padilla \& Williams, 2004). To date, 96 aquatic plant species from 30 families have been reported as aliens in at least one of the 46 European countries (Hussner, 2012). Most exotic aquatic plant species have been introduced from areas with mild climates (Mediterranean, tropical or neotropical) via garden centres and the aquarium trade (Padilla \& Williams, 2004). Of the 36 exotic plant species (aquatic and riparian) recorded in France, the most recently introduced are all species typically found in aquaria. Examples include Myriophyllum heterophyllum (Michx.), Cabomba caroliniana (Gray) and Althernanthera philoxeroides ((Mart.) Griseb.). As the trade in ornamental species is clearly the major pathway for introduction of alien aquatic plants in France, prohibition of the import and sale of potentially invasive species would appear to be the most effective option for reducing the risk of further introductions. A recent study (Hussner et al., 2014) has indicated that 19 of the 27 alien aquatic plant species presently known from German freshwaters were still being traded as ornamental species for aquaria and garden ponds, despite 11 of the species being well-known invasive pest species that were already blacklisted. Following a European Union recommendation, several countries have now implemented "codes of conduct" (i.e. voluntary agreements) to regulate trading in aquatic plants for aquaria and water gardening (Verbrugge et al., 2014). While such codes of conduct for the horticultural sector have become a popular policy instrument, their efficiency still needs to be improved. The contrast between the implementation of codes of conduct and the trade currently in place highlights the difficulty of implementing laws or agreements regulating trade in blacklisted plant species, despite a relatively high 

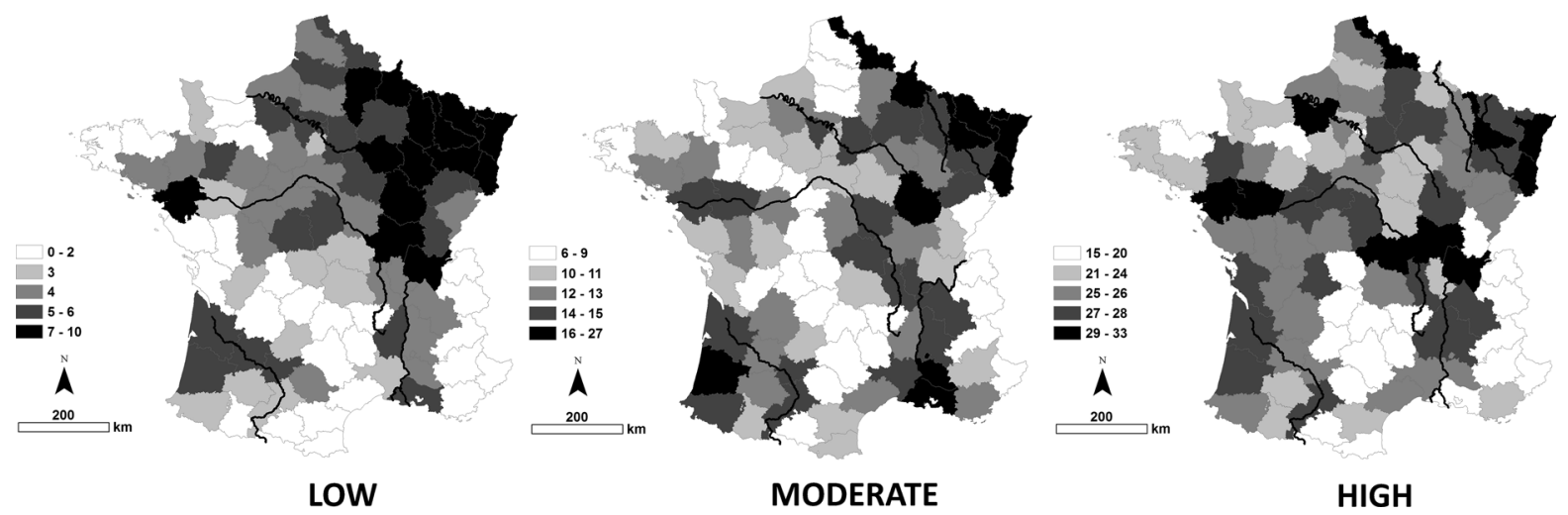

Fig. 5 Number of species in each county according to their potential level of impact (low, moderate, high, ESM_3)

level of awareness among the public, scientists and decision-makers.

As part of the implementation of EU Regulation No. 1143/2014 (22 October 2014), a list of invasive alien species of trans-Union concern has been established in Annex B to Council Regulation (EC) No 338/97. Priority has been given to invasive exotic animal species for which importation and trade is already forbidden in the European Union (e.g. Oxyura jamaicensis (Gmelin) (duck), Lithobates (Rana) catesbeianus (Shaw) (frog), Chrysemys picta (Schneider) and Trachemys scripta elegans (Wied) (turtles); aquatic species only). An initial list of invasive alien species of Union concern, including animal and plant species, pursuant to Article 4(1) of EU Regulation No. 1143/2014 was published in July 2016 (Commission implementing regulation (EU) 2016/1141 of 13 July 2016). Member states may submit a request to the Commission for inclusion of invasive exotic species onto the list, a process beyond the scope of this paper. This list has huge potential as, according to Article 7 of the regulation, invasive alien species listed as of Union concern 'shall not be intentionally (a) brought into the territory of the Union, including transit under customs supervision; (b) kept, including in contained holdings; (c) bred, including in contained holdings; (d) transported to, from or within the Union, except for the transportation of species to facilities in the context of eradication; (e) placed on the market; (f) used or exchanged; (g) permitted to reproduce, grown or cultivated, including in contained holdings; or (h) released into the environment'. It further states that member states shall take all necessary steps to prevent the unintentional introduction or spread of invasive alien species of Union concern, including by 'gross negligence'. This article means that there is now a legislative framework and instrument in place to help minimise and mitigate the adverse impacts of the introduction (whether intentional or unintentional) and spread of invasive exotic species on European Union biodiversity (including aquatic ecosystems). It remains to be seen how this text will be implemented.

Our data indicate that counties along the west coast of France had highest numbers of exotic plant introductions. These areas include the alluvial downstream stretches of a number of large rivers (the Rivers Garonne, Loire and Seine) that flow from the east to the Atlantic Ocean. The rich wetlands associated with these river basins provide a wide variety of aquatic habitats for introduced species. On a larger scale, Hussner (2012) has noted that Italy and France have the highest number of alien aquatic (non-riparian) plant species in Europe, with 34 species in Italy and 32 in France (total in Europe $=96$ species; Hussner, 2012). In comparison, Germany has 27 alien aquatic plant species, Belgium and Hungary 26 and the Netherlands 24. Most aquatic plant invasions have tended to occur from West to East, with species such as Ludwigia (L.) being first recorded in France or the Benelux countries (Hussner, 2012). As freshwater aquatic plant species generally have broad distribution ranges limited almost solely by geographical barriers or major disjunctions between climatic regions (Santamaría, 2002) exotic species in France and Italy may be expected to serve as source populations for later spreading throughout Europe. According to Nunes et al. (2015), however, France is not the main entrance point for exotic species into Europe (all taxonomic 
groups considered); instead, the UK (90 species introduced), Italy (73), Russia (63), Austria (51) and Ireland (37) were by far the most important gateways.

\section{Exotic plants and animals show reverse geographic} patterns

The heterogeneity in spatial distribution of exotic plants and animals highlighted in this study reflects their mode of introduction. While there are a wide range of possible introduction routes for exotic animal species, high-density species with a holobiotic cycle (i.e. all developmental stages aquatic) show a high probability of becoming boat 'hitchhikers'. The Rhine, which acts as a highway for boats and shipping through one of the most important economic regions of Europe, has clearly been the main entrance point for the dispersal of invasive aquatic animal species in France over recent decades (Devin et al., 2005). In addition, the intensively used navigable stretches of the Rivers Rhone and Rhine/Meuse connect the Mediterranean with the north of Europe along a roughly north-south axis. These riverine routes have favoured the spread of exotic animal species; with highest numbers clearly distributed along counties bordering the Meuse, Moselle, Rhine and Rhone (see Fig. 3). This is basically the reverse of exotic plant distribution in France, which is mainly distributed along the west coast (see previous section). This dichotomy in species distribution means that prevention of the spread of exotic species is addressed differently in the east and west of France. As prevention is more effective than eradication, it is essential that the spread of exotic species into territories where they have not yet been observed is prevented. For this reason, greater effort is presently needed to prevent plant invasions in areas where invasive animals are already abundant and require management (i.e. the north-east) and, conversely, more effort must be given towards prevention of animal invasions in those areas where invasive plants are already common (i.e. the west).

Over the last 200 years, the total river catchment surface area connected to the Rhine via inland waterways has increased by a factor of 21.6 (Leuven et al., 2009). No less than six principal invasion corridors have been identified for aquatic species entering the Rhine (Bij de Vaate et al., 2002; Leuven et al., 2009). Of these, the so-called Southern Route, or the Danube-Main-Rhine corridor, has seen especially high numbers of invasive species over recent decades, many originating from the Ponto-Caspian region in the east (see Roche et al., 2013 regarding the spread of gobiid fishes). Today, the Rhine basin represents a clear hotspot for xenodiversity in Western Europe and now acts as a source for introductions into adjacent river basins.

Not all exotic species have come from the PontoCaspian area, however, nor have all first observations of exotic animal species occurred in the north-east of France. The Chinese pond mussel Sinanodonta woodiana (Lea), for example, was first observed in the Camargue (in the 1980s), then in the Rhone (2007), before its first appearance in the west (2011) and north-east of France in 2014 (Thomas \& Chovet, 2013 and unpublished data). This unusual introduction pattern was a direct result of the overland introduction of the Chinese (or Amur) carp Ctenopharyngodon idella (Valenciennes) on which $S$. woodiana 'hitchhike' as parasitic glochidia larvae attached to the gills. Today, there is an incredible melting pot of exotic species entering the Rhine (Beisel, 2001), with introductions coming from almost everywhere in Europe and around the world, often via complex routes. For example, a recent analysis by Marescaux et al. (2016) provides strong evidence that the invasion of the Ponto-Caspian quagga mussel Dreissena bugensis (Andrusov) into north-west Europe (first observed in France in 2011; Bij de Vaate \& Beisel, 2011) was a 'return invasion' from North America, where the species appears to have been introduced from the Ponto-Caspian region around 1989 (Karatayev et al., 2015).

Natural and/or human-aided dispersal explains actual distribution of exotic species

While the spread of any species can be promoted through human activity, some can also utilise their own dispersal abilities (see Havel et al., 2015). Birds, fish and mammals, for example, have a naturally increased dispersal capacity, and this can greatly enhance their speed of invasion following dispersal events from human-aided transport. Invertebrates and amphibians, on the other hand, usually have short generation times, making 'natural' large-scale movements unlikely. Despite this, the role of natural vectors in the largescale dispersal of invertebrates, amphibians and plants 
has probably been under-estimated in invasion ecology (Green, 2016). Hitchhiking plants and small animals may also be carried by a variety of human vectors (Havel \& Shurin, 2004; Padilla \& Williams, 2004). Subsequently, most exotic aquatic invertebrates not only tend to spread naturally into adjacent areas, but may also continue 'hitchhiking' with humans (e.g. via recreational boats) into further new areas. Where exotic species have entered France via the Rhine, spreading has tended to occur as a slow 'wave' into other large river basins, with the original introductions still visible as a 'clump' in the north-east after several decades (Beisel et al., unpublished data).

The French government presently has plans to develop or improve the inland waterway network in order to accommodate larger vessels and increase inland shipping, especially in the north of France. The Seine-North Europe Canal Project will include the construction of a wide $100 \mathrm{~km}$ canal between the Oise (a Seine tributary, near the town of Compiegne) and the Dunkerke-Escaut Canal (near Cambrai). The result will be a major transportation network linking France with Belgium and onward into Germany and The Netherlands. In the past, the opening of new inland waterways has facilitated both active and passive dispersal of invasive species across Eurasian inland waters and coastal ecosystems (Bij de Vaate et al., 2002; Leuven et al., 2009). Paradoxically, it has recently been recognised that modern biological conservation efforts to implement long-term projects for restoring terrestrial and aquatic ecological continua through construction of 'green and blue corridors' can also have negative impacts, favouring dispersal of invasive species at both the local and wider scale (Dutartre \& Mazaubert, 2014). There is an urgent requirement, therefore, to implement appropriate risk assessment tools prior to such new waterway developments in order to address the potential ecological and socio-economic risks posed by the potential new wave of exotic species that may result and to formulate sound preventive measures and management options.

While longitudinal watershed connectivity and the impact of shipping have had a major impact on exotic species introduction in France, the impact of aquaculture and the pet/aquarium/terrarium trade as important pathways of initial introduction into Europe should also not be under-estimated (Nunes et al., 2015; e.g. see Chinese carp and $S$. woodiana above).
Increased potential impact everywhere, but for different reasons

The cumulative effect of the total exotic species assemblage (the 'xenodiversity' of Leppäkoski et al., 2002) has rarely been estimated on a large scale. In our study, the sum of exotic species (high, medium and low impact species together) in each county indicated a high-potential risk in all counties with navigable waterways. Five counties (downstream Seine, Escaut, River Moselle, Upper Rhine, Middle Rhone) had particularly high-impact scores, and these were all counties with intense navigation and heavily modified landscapes. Furthermore, most counties with highcumulative impact scores were situated in the northeast of France, making this the most threatened region in France (see Fig. 5).

In order to adequately understand the effects of introduced exotic species, it is important that both functional distinctiveness and abundance are considered (Vitousek, 1990; Parker et al., 1999). As ecological and evolutionary processes can change over time, both these factors can be modulated by 'time since introduction' (Strayer et al., 2006). In our study, we were unable to consider distinctiveness (i.e. how much exotic species' characteristics differ from those of species already in the community) as this is best appreciated at a local scale, rather than at a national or global scale. Regarding abundance (or density), most exotic species observed in France have the potential to become invasive. For them, however, abundances have remained (and are likely to remain) at levels that facilitate their integration without fundamental changes to the rest of the community. Furthermore, potential impacts appear to be kept at low levels as population growth has remained sporadic (e.g. in the Bryozoa Plumatella fungosa (Pallas)) or the species concerned are very small (e.g. the crustacean Jaera istri (Veuille), $\leq 5 \mathrm{~mm}$ in length). Indeed, most exotic species appear to have a minimal environmental impact, with just a small fraction causing major problems (Gherardi et al., 2009). As an example, of the three gobiid species recently introduced into France, the tubenose goby Proterorhinus semilunaris (Heckel) is rarely observed at high density (Manné et al., 2013) and is not of particular concern in large rivers. On the other hand, several native species appear to have decreased in density as round goby Neogobius melanostomus (Pallas) numbers have increased (Beisel et al., unpublished data). 
Twenty-five of the exotic species in our list (ESM_2) are included among the DAISIE consortium's '100 worst invasive species of Europe' (Gherardi et al., 2009), and 11 among IUCN's list of worst invasive species in the world (Lowe et al., 2000; modified in 2013). As six of these species are included in both lists, 30 of the 148 exotic species recorded in France $(20 \%)$ are included in one or other of the ' 100 worst invasive species' lists. Overall, 30\% of all alien freshwater species in France have an ecological impact on the ecosystem, with $24 \%$ having an economic impact. This is a much higher proportion than in terrestrial habitats (Vilà et al., 2010; Hussner, 2012).

To conclude, this spatiotemporal analysis offers a general point of reference for the main river basins affected by introduced exotic species in France and, as such, should prove useful for both scientists and stakeholders working in France and its neighbours. In compiling our data, we noticed a problem that some species (e.g. the muskrat Ondatra zibethicus (L.)) have become so widespread and common (or popular) throughout the country that their spatial distribution is no longer registered as nobody pays them any attention. Other species have been present in France for long periods (e.g. the zebra mussel Dreissena polymorpha (Pallas), introduced in the nineteenth century) and are assumed to be present everywhere. However, our data indicate that many such species still have limited distributions around the country. Clearly, new investigations are needed for these latter species and we strongly suggest new standardised nationwide surveys as a next step to improving our knowledge of the present situation regarding exotic and invasive species in France.

Acknowledgments We are grateful to the French Rhin-Meuse Water Agency (Agence financière de Bassin Rhin-Meuse), which supported our research within the framework of a study on Biological Invasions from 2010 to 2013. We would also like to thank Marie Vanacker, who helped complete the distribution database of invasive species in France. We are very grateful to Kevin Roche for linguistic correction. The remarks and advice of the Associate Editor, Dr John Havel, and three anonymous reviewers helped to improve this manuscript, for which we are sincerely grateful. This paper is dedicated to our colleague Nathalie Kleinen, who passed away too early (June 2016).

\section{References}

Bachmann, V., P. Usseglio-Polatera, E. Cegielka, P. Wagner, J.F. Poinsaint \& J.-C. Moreteau, 1997. Premières observations sur la coexistence de Dreissena polymorpha,
Corophium curvispinum et Corbicula spp. dans la rivière Moselle. Bulletin français de la pêche et de la pisciculture 344-345: 373-384.

Beisel, J. N., 2001. The elusive model of a biological invasion process: time to take differences among aquatic and terrestrial ecosystems into account? Ethology, Ecology and Evolution 13: 193-195.

BFPP, 1997. Les introductions d'espèces dans les milieux aquatiques continentaux en métropole. Bulletin Français de la Pêche et de la Pisciculture 344-345, 513 pp.

Bij de Vaate, A. \& J. N. Beisel, 2011. Range expansion of the quagga mussel Dreissena rostriformis bugensis (Andrusov, 1897) in Western Europe: first observation from France. Aquatic Invasions 6: 71-74.

Bij de Vaate, A., K. Jazdzewski, H. A. M. Ketelaars, S. Gollasch \& G. Van der Velde, 2002. Geographical patterns in range extension of Ponto-Caspian macroinvertebrates species in Europe. Canadian Journal of Fisheries and Aquatic Sciences 59: 1159-1174.

Bobeldyk, A. M., J. Rüegg \& G. A. Lamberti, 2015. Freshwater hotspots of biological invasion are a function of speciespathway interactions. Hydrobiologia 746: 363-373.

Butler, D., 2012. Europe on alert for flying invaders. Nature 489: $187-188$.

Caffrey, J. M., J. R. Baars, J. H. Barbour, P. Boets, P. Boon, K. Davenport, J. T. A. Dick, J. Early, L. Edsman, C. Gallagher, J. Gross, P. Heinimaa, C. Horrill, S. Hudin, P. E. Hulme, S. Hynes, H. J. MacIsaac, P. McLoone, M. Millane, L. Moen, N. Moore, J. Newman, R. O'Conchuir, M. O'Farrell, C. O'Flynn, B. Oidtmann, T. Renals, A. Ricciardi, H. Roy, R. Shaw, C. H. van Valkenburg, O. Weyl, F. Williams \& F. E. Lucy, 2014. Tackling invasive alien species in Europe: the top 20 issues. Management of Biological Invasions 5(1): 1-20.

Devin, S., L. Bollache, P. Y. Noël \& J. N. Beisel, 2005. Patterns of biological invasions in French freshwater systems by non-indigenous macroinvertebrates. Hydrobiologia 551: 137-146.

Dewas, M., J. Herr, L. Schley, C. Angst, B. Manet, P. Landry \& M. Catusse, 2012. Recovery and status of native and introduced beavers Castor fiber and Castor canadensis in France and neighbouring countries. Mammal Review 42(2): 144-165.

Dutartre, A. \& E. Mazaubert, 2014. La mise en œuvre de la Trame verte et bleue: un vecteur supplémentaire de dispersion des espèces invasives? Sciences Eaux \& Territoires 14: 58-63.

Dutartre, A., E. Mazaubert \& N. Poulet, 2012. Bilan des espèces exotiques envahissantes en milieux aquatiques sur le territoire français: essai de bilan en métropole. Sciences Eaux et Territoires 6: 56-63.

EEA, 2012. The impacts of invasive alien species in Europe. European Environment Agency Technical report No 16, $114 \mathrm{pp}$.

Forcellini, M., 2012. First record of the ponto-caspian invasive crustacean Chelicorophium sowinskyi (Martynov, 1924) (Amphipoda, Corophiidae) in the French Rhône River. Crustaceana 85(14): 1781-1785.

Gherardi, F., 2007. Biological invasions in inland waters: an overview. In Gherardi, F. (ed.), Biological invaders in inland waters: profiles, distribution, and threats. Springer, Dordrecht: 3-25. 
Gherardi, F., S. Gollasch, D. Minchin, S. Olenin \& V. E. Panov, 2009. Alien invertebrates and fish in European inland waters. In Delivering Alien Invasive Species Inventories for Europe [DAISIE] (eds), Handbook of Alien Species in Europe. Invading Nature - Springer Series in Invasion Ecology, Volume 3: 81-92.

Green, A. J., 2016. The importance of waterbirds as an overlooked pathway of invasion for alien species. Diversity Distrib. 22: 239-247.

Havel, J. E. \& J. B. Shurin, 2004. Mechanisms, effects, and scales of dispersal in freshwater zooplankton. Limnology and Oceanography 49: 1229-1238.

Havel, J. E., K. E. Kovalenko, S. M. Thomaz, S. Amalfitano \& L. B. Kats, 2015. Aquatic invasive species: challenges for the future. Hydrobiologia 750(1): 147-170.

Holdich, D. M., J. D. Reynolds, C. Souty-Grosset \& P. J. Sibley, 2009. A review of the ever increasing threat to European crayfish from non-indigenous crayfish species. Knowledge and Management of Aquatic Ecosystems 394-395: 11.

Hulme, P. E., D. B. Roy, T. Cunha \& T. B. Larsson, 2009. A panEuropean inventory of alien species: rationale, implementation and implications for managing biological invasions. In Delivering Alien Invasive Species Inventories for Europe [DAISIE] (eds), Handbook of Alien Species in Europe. Invading Nature - Springer Series in Invasion Ecology, Volume 3: 1-14.

Hussner, A., 2012. Alien aquatic plant species in European countries. Weed Research 52(4): 297-306.

Hussner, A., S. Nehring \& S. Hilt, 2014. From first reports to successful control: a plea for improved management of alien aquatic plant species in Germany. Hydrobiologia 737(1): 321-331.

Karatayev, A. Y., L. E. Burlakova \& D. K. Padilla, 2015. Zebra versus quagga mussels: a review of their spread, population dynamics, and ecosystem impacts. Hydrobiologia 746: 97-112.

Labat, F., C. Piscart \& B. Fontan, 2011. First records, pathways and distributions of four new Ponto-Caspian amphipods in France. Limnologica-Ecology and Management of Inland Waters 41(4): 290-295.

Leppäkoski, E., S. Gollasch \& S. Olenin, 2002. Alien species in European waters. In Leppäkoski, E., S. Gollasch \& S. Olenin (eds), Invasive aquatic species of Europe: distribution, impact and management. Kluwer Academic Publisher, Dordrecht: 1-6.

Leuven, R. S., G. van der Velde, I. Baijens, J. Snijders, C. van der Zwart, H. R. Lenders \& A. Bij de Vaate, 2009. The river Rhine: a global highway for dispersal of aquatic invasive species. Biological Invasions 11(9): 1989-2008.

Lowe, S., M. Browne, S. Boudjelas \& M. De Poorter, 2000. 100 of the world's worst invasive alien species. A selection from the Global Invasive Species Database. Published by The Invasive Species Specialist Group (ISSG) a specialist group of the Species Survival Commission (SSC) of the World Conservation Union (IUCN), pp 12.

Manné, S., N. Poulet \& S. Dembski, 2013. Colonisation of the Rhine basin by non-native gobiids: an update of the situation in France. Knowledge and Management of Aquatic Ecosystems 411: 02 .
Marescaux, J., K. C., von Oheimb, E. Etoundi, P. V. von Oheimb, C. Albrecht, T. Wilke \& K., Van Doninck, 2016. Unravelling the invasion pathways of the quagga mussel (Dreissena rostriformis) into Western Europe. Biological Invasions 18: 245-264.

Mazza, G., E. Tricarico, P. Genovesi \& F. Gherardi, 2014. Biological invaders are threats to human health: an overview. Ethology Ecology \& Evolution 26(2-3): 112-129.

Moutou, F., 1997. Mammifères aquatiques et semi-aquatiques introduits en France. Risques et conséquences. Bulletin Français de la Pêche et de la Pisciculture 344-345: 133-139 (in French).

Nunes, A. L., E. Tricarico, V. E. Panov, A. C. Cardoso \& S. Katsanevakis, 2015. Pathways and gateways of freshwater invasions in Europe. Aquatic invasions 10: 359-370.

Padilla, D. K. \& S. L. Williams, 2004. Beyond ballast water: aquarium and ornamental trades as sources of invasive species in aquatic ecosystems. Frontiers in Ecology and the Environment 2: 131-138.

Pagnucco, K. S., G. A. Maynard, S. A. Fera, N. D. Yan, T. F. Nalepa \& A. Ricciardi, 2015. The future of species invasions in the Great Lakes-St. Lawrence River basin. Journal of Great Lakes Research 41: 96-107.

Parker, I. M., D. Simberloff, W. M. Lonsdale, K. Goodell, M. Wonham, P. M. Kareiva, M. H. Williamson, B. Von Holle, P. B. Moyle, J. E. Byers \& L. Goldwasser, 1999. Impact: toward a framework for understanding the ecological effects of invaders. Biological invasions 1(1): 3-19.

Piscart, C. \& L. Bollache, 2012. Introduction pratique à la systématique des organismes des eaux continentales de France. 11. Crustacés Amphipodes de surface (Gammares d'eau douce). Association Française de Limnologie.

Richardson, D. M., P. Pyšek, M. Rejmánek, M. G. Barbour, F. D. Panetta \& C. J. West, 2000. Naturalization and invasion of alien plants: concepts and definitions. Diversity and distributions 6(2): 93-107.

Roche, K. F., M. Janáč \& P. Jurajda, 2013. A review of Gobiid expansion along the Danube-Rhine corridor - geopolitical change as a driver for invasion. Knowledge and Management of Aquatic Ecosystems 411: 01.

Santamaría, L., 2002. Why are most aquatic plants widely distributed? Dispersal, clonal growth and small-scale heterogeneity in a stressful environment. Acta oecologica 23(3): 137-154.

Strayer, D. L., V. T. Eviner, J. M. Jeschke \& M. L. Pace, 2006. Understanding the long-term effects of species invasions. Trends in Ecology \& Evolution 21(11): 645-651.

Thomas, A. \& M. Chovet, 2013. Découverte de l'Anodonte chinoise Sinanodonta woodiana (Lea, 1834) (Mollusca, Bivalvia, Unionidae) dans le canal d'Orléans (Loiret, France). MalaCo 9: 463-466 (in French).

Verbrugge, L. N., R. S. E. W. Leuven, J. L. C. H. Van Valkenburg \& R. J. van den Born, 2014. Evaluating stakeholder awareness and involvement in risk prevention of aquatic invasive plant species by a national code of conduct. Aquatic Invasions 9: 369-381.

Vilà, M., C. Basnou, P. Pyšek, M. Josefsson, P. Genovesi, S. Gollasch, W. Nentwig, S. Olenin, A. Roques, D. Roy, P. 
E. Hulme \& DAISIE partners, 2010. How well do we understand the impacts of alien species on ecosystem services? A pan-European, cross-taxa assessment. Frontiers in Ecology and the Environment 8(3): 135-144.
Vitousek, P. M., 1990. Biological invasions and ecosystem process - towards an integration of population biology and ecosystem studies. Oikos 57: 7-13. 